\title{
ERYTHROCYTES LEVEL AND ITS CORRELATION WITH CHOLINESTERASE LEVEL IN FARMERS WHO USE PESTICIDE: META-ANALYSIS
}

\author{
Arum Nuryati \\ Masters Program in Public Health, Universitas Sebelas Maret
}

\begin{abstract}
Background: In the last five decades pesticide use has increased sharply in the pursuit of increasing agricultural production. Organophosphates (OP) have been used as pesticides in countries where considerable agricultural activities are performed for more than 50 years. Pesticide use suggests a risk of significant exposures and intoxications among farmers. Organophosphates is potent cholinesterase. The acute intoxications caused by cholinesterase inhibitors which capable of causing severe cholinergic toxicity following cutaneous exposure, inhalation, or ingestion. This study aimed to examine erythrocytes level and its correlation with cholinesterase level in farmers who use pesticide.
\end{abstract}

Subjects and Method: A systematic review and meta analysis was conducted by collecting articles from Pubmed, Scopus, Science Direct, Google Scholar, and Medline databases. The determination of selected articles based on eligible criteria using PICO: (1) Population = farmers who used pesticide, (2) Intervention= normal erythrocytes, (3) Comparison= low erythrocytes level, and (4) Outcome $=$ cholinesterase. Keywords used "Red Blood Cell" OR "Cholinesterase Level" AND "Farmers" OR "Cholinesterase Level" AND "Exposed to Pesticides" OR "Farmers" OR "Non Farmers". The inclusion criteria were English full text, case control study, published from 2008 to 2021, and reported Standardized Mean Difference. The articles were collected by PRISMA flow diagram. The selected articles were quantitatively examined by Review Manager 5.4.

Results: A meta-analysis consisted of 7 studies from Thailand, Philippines, India, Nepal, Brazil, and Nigeria. This study showed that erythrocytes reduces cholinesterase level in farmers, but it was statistically non-significant (SMD $=-0.18 ; 95 \% \mathrm{CI}=-0.68$ to $0.32 ; \mathrm{p}=0.490$ ).

Conclusion: Erythrocytes reduces cholinesterase level in farmers, but it was statistically non-significant.

Keywords: erythrocytes, cholinesterase levels, farmers

\section{Correspondence:}

Arum Nuryati. Masters Program in Public Health, Universitas Sebelas Maret. Jl. Ir. Sutami 36A, Surakarta 57126, Central Java. Email: arumnuryati@student.uns.ac.id. Mobile: +6285728792097 . 